This item was submitted to Loughborough's Research Repository by the author.

Items in Figshare are protected by copyright, with all rights reserved, unless otherwise indicated.

\title{
Urban economies and the dead woman muse in the poetry of Amy Levy and Djuna Barnes
}

PLEASE CITE THE PUBLISHED VERSION

https://www.routledge.com/products/9781138826342

PUBLISHER

(c) Taylor \& Francis

VERSION

AM (Accepted Manuscript)

\section{PUBLISHER STATEMENT}

This work is made available according to the conditions of the Creative Commons Attribution-NonCommercialNoDerivatives 4.0 International (CC BY-NC-ND 4.0) licence. Full details of this licence are available at: https://creativecommons.org/licenses/by-nc-nd/4.0/

\section{LICENCE}

CC BY-NC-ND 4.0

\section{REPOSITORY RECORD}

Parker, Sarah. 2015. "Urban Economies and the Dead Woman Muse in the Poetry of Amy Levy and Djuna Barnes”. Loughborough University. https://hdl.handle.net/2134/20850. 


\section{Urban Economies and the Dead-Woman Muse in the Poetry of Amy Levy and Djuna}

\section{Barnes}

\section{The Dead Woman as Muse}

This chapter addresses, for the first time, the revealing continuities between the late Victorian poet and novelist Amy Levy (1861-1889) and the American modernist Djuna Barnes (18921982). ${ }^{1}$ During the latter half of the twentieth century, both poets enjoyed a critical revival which focussed on the complex portrayal of identity in their work, particularly their constructions (and deconstructions) of gender, sexuality, race, ethnicity and religion. Thematically, their poetry exhibits striking parallels—as suggested by the kinds of critical attention that their work has tended to attract. Both Levy’s and Barnes’s work has individually been frequently read in terms of gender identity, the New Woman, diasporic and abject identities, lesbian identity, Jewish identity, urban space, and modernity.

However, persistent demarcations between the Victorian and the Modern have meant that critics have yet to fully consider the parallels between their works: parallels which reveal productive insights into gender identity, the new urban woman, and queer desire. My aim in this chapter is, therefore, to compare their poetry and simultaneously, to probe the more troubling aspects of their work, by focusing particularly on Levy's and Barnes’s shared portrayal of the dead woman as muse. Their poems uncover the ways in which the new urban woman was endangered by her presence in the city street, objectified by the male gaze and threatened by male violence (most notoriously, in the case of Jack the Ripper, whose murders

\footnotetext{
${ }^{1}$ Amy Levy (1861-1889) is perhaps most remembered for her novel Reuben Sachs (1889), which depicts Jewish life in London in the late nineteenth-century. Her poetic volumes are Xantippe and Other Verse (1881), A Minor Poet and Other Verse (1884) and A London Plane-Tree, and Other Verse (1889). The corrected proofs for this final volume were discovered on Levy's desk when she committed suicide at the age of twenty-seven. Djuna Barnes (1892-1982) remains synonymous with her modernist masterpiece Nightwood (1936). Her distinctive prose style - also exhibited in Ryder and Ladies Almanack (both 1928) — frequently combines Gothic, Baroque and Renaissance-inflected archaisms. Barnes also published journalism, drama, poetry, and illustrated her own works. The Book of Repulsive Women (1915) is, for example, accompanied by five drawings in a distinctive black-andwhite style, reminiscent of Aubrey Beardsley's illustrations for Salomé (1891).
} 
took place at the time Levy was writing). In both poets’ work, female corpses are categorized and commoditized, suggesting that women, whether living or dead, are entrapped within a system of urban consumption that denigrates the female body. In this sense, their poetry constitutes a reflection on the libidinal economies of the city space, in which the new public woman is revealed to be a victim of ruthless capitalist logic, circulating as a ghostly reminder of the price of so-called liberation. ${ }^{2}$

The dead-woman muse is a ghostly presence that haunts both Levy's and Barnes's bodies of work with startling persistence, as critics of both poets have noted. For instance, Rebecca Loncraine observes that Barnes is "preoccupied with images of the body, and especially the corpse. Her muse is a dead woman” (2003, 42), whilst Emma Francis remarks that Levy’s lyric poems frequently "use death as lexicon through which the speakers seek to understand their experience” $(1999,190)$. However, despite these continuities, Levy’s and Barnes's representations of the dead-woman muse exhibit subtle distinctions. In Amy Levy's work, particularly in her final volume A London Plane-Tree, and Other Verse (1889), this dead woman appears primarily as a hazy urban spectre; in the unsettling lyric entitled "In the Mile End Road," the beloved appears to walk up "the crowded street” towards the speaker (50). At the poem's close, the speaker suddenly recollects "My only love was dead" (50), revealing this to be an impossible encounter. ${ }^{3}$ Elsewhere in the volume, this sense of the uncanny endures, since in numerous poems particularly in a sub-section entitled "Love, Dreams, and Death”- speakers are visited by disembodied spirits that subtly permeate their dreams, such as in "Borderland":

As the first faint dawn comes creeping

Thro' the pane, I am aware

Of an unseen presence hovering,

Round, above, in the dusky air $(1889,42)$

\footnotetext{
${ }^{2}$ As Renée L. Bergland observes, the ghostly trope has frequently been used to represent 'political and economic power relations' - for example, the spectre of Communism haunting Europe at the beginning of The Communist Manifesto (Bergland 2000, 7).

${ }^{3}$ All subsequent references to Amy Levy’s poetry are from A London Plane-Tree, and Other Verse. London: T. Fisher Unwin, 1889, unless otherwise indicated.
} 
In marked contrast to such airy visitations, Barnes’s dead beloved is portrayed as grotesquely corporeal. Less a ghost, more a corpse, Barnes finds inspiration in a dead woman whose material reality is unassailable. For example, in "The Flowering Corpse” (1923), a beloved woman's body nourishes the earth, causing flowers and ferns to sprout:

Over the body and the quiet head

Like stately ferns above an austere tomb,

Soft hairs blow; and beneath her armpits bloom

The drowsy passion flowers of the dead. $(2005,91)^{4}$

As the final poem in The Book of Repulsive Women (1915), Barnes presents us with "Suicide: Corpse B”: "Her body shock-abbreviated / As a city cat” (2005, 55). The darkly comic edge of such poems echoes Barnes’s Vanity Fair article (published under her pseudonym, Lydia Steptoe) entitled "What Is Good Form in Dying? In Which a Dozen Dainty Deaths Are Suggested for Daring Damsels” (1923). In this article, Barnes advises on elegant modes of suicide, unnervingly combining this with the flippant rhetorical style of a fashion magazine: advising that blondes, for example, "hang sweetly, debonairly, and perseveringly by the neck,” while brunettes should drink “slow green poison” (Steptoe 1923, 73). In this sense, Barnes’s corpses are shockingly commodified. Throughout her oeuvre she consistently points up parallels between the female corpse feeding the earth, and the woman's body as urban detritus, promiscuously circulating through the city space, eternally bound to perform the role of fashion victim and object of the gaze, even after her death. Through the dead-woman muse, Barnes articulates her critique of a modernity that holds out the promise of female liberation, while women in fact remain stuck in an economic system that constantly depreciates their value. Of course, the dead woman is part of a tradition that reaches far beyond Levy's and Barnes’s work. Elisabeth Bronfen’s seminal study Over Her Dead Body: Death, Femininity and the Aesthetic (1992) documents the persistent presence of the dead woman throughout literary history. Taking her cue from Edgar Allan Poe’s assertion that "the death of a beautiful

\footnotetext{
${ }^{4}$ All subsequent references to Djuna Barnes’ poetry are from Phillip Herring and Osías Stutman, ed. Djuna Barnes: Collected Poems, with Notes towards the Memoirs.Wisconsin: University of Wisconsin Press, 2005. Print unless otherwise indicated.
} 
woman is, unquestionably, the most poetical topic in the world” (Poe 1846, 165), Bronfen explores the appeal of this trope that recurs throughout art and literature, from Samuel Richardson’s Clarissa (1748) to Vladimir Nabokov’s Lolita (1955). Using psychoanalytical theory, Bronfen considers why death, femininity and the image of the dead woman are consistently linked in the work of male artists and writers. She concludes that the dead woman in art serves "as a displaced signifier for masculinity, survival, preservation and continuation” (Bronfen 1992, 433), and is obsessively invoked as a way of warding off the threat of annihilation:

The beauty of Woman and the beauty of the image both give the illusion of intactness and unity, cover the insupportable signs of lack, deficiency, transiency and promise their spectators the impossible - an obliteration of death's ubiquitous 'castrative' threat to the subject. (Bronfen 1992, 64)

However, such repression is always doomed to fail, particularly since the actual act of representation 'kills' the living feminine body_to whom it ostensibly refers_-into a 'dead' image: “Beauty, however, always also includes death’s inscription, because it requires the translation (be it in fantasy or in reality) of an imperfect, animate body, into a perfect, inanimate image, a dead 'figure”' (Bronfen 1992, 64).

In order to understand how Levy and Barnes manipulate this trope, it is necessary to contextualize the dead-woman muse in terms of the concept of the muse more generally. Throughout literary tradition, the muse has served as the passive signifier of the male artist's active inspiration: the vessel through which he expresses his subjectivity. This muse-poet dynamic has been gendered throughout literary history; from the earliest appearance of the nine muses in Ancient Greek mythology, to Dante’s Beatrice and beyond, the muse has consistently appeared as a beautiful feminine figure. Even when the muse's image is based on that of a real, living woman, the image projected in art or poetry is composed primarily by the male artist's shaping imagination, formed from the 'raw material' that her living presence provides. To the extent that she serves as object of the poet's desire, and inspiration for his art, the muse is the poet's opus. She does not have (as far as he is concerned) an identity 
outside of his objectifying gaze. Christina Rossetti—who had modelled for her brother's paintings, and witnessed his relationships with various muse-figures such as Elizabeth Siddal— explored this discrepancy between the living woman and the artist's muse in her poem “In an Artist’s Studio” (written 1856):

He feeds upon her face by day and night,

And she with true kind eyes looks back on him,

Fair as the moon and joyful as the light:

Not wan with waiting, not with sorrow dim;

Not as she is, but was when hope shone bright;

Not as she is, but as she fills his dream. (Rossetti 2008, 49)

The dynamic described in Rossetti's poem, in which (from the male artist's perspective) the “dead” artistic representation of the model is preferable to her living reality, in part explains the popularity of the dead woman as the ultimate muse figure. As suggested by Bronfen, in performing the role of muse, a woman becomes nothing more (or less) than a dead image of perfection. This transmogrification is more easily accomplished if the living woman is no longer there. In other words, if the "real” woman is absent, her image can be reconstituted with abandon, free from the troubling alterity announced by her actual presence. In this sense, the dead woman and the concept of the muse are inextricably connected; every muse is in some sense a dead woman.

Thus, poetic inspiration, death and femininity become enmeshed through centuries of art and literature, so that the image of the dead woman comes to serve as a commentary on the creation of art itself:

Because her dying figures as an analogy to the creation of an art work, and the depicted death serves as a double of its formal condition, the 'death of a beautiful woman' marks the mise en abyme of a text, the moment of self-reflexivity, where the text seems to comment on itself and its own process of composition, and so decomposes itself. (Bronfen 1992, 71) 
But what does the prevalence of the dead-woman muse mean for a woman writer? If, in the prevailing cultural mythos, the creation of art can only be accomplished through female destruction, how can a living woman assert her own power to create art, without falling victim to this potentially self-annihilative narrative? For in the case of women writers, the deadwoman muse comes to represent not the imagined annihilation of the other, but the female artist’s own death or self-destruction. Bronfen suggests a number of strategies by which women writers may attempt to subvert this destructive dynamic. Chief among these is what she terms a "hysteric strategy": a strategy by which women writers repeat and parody the conventions of male literary tradition. This exposes such male conventions to strip them of their power and authority: "hysterical writing installs conventions such as the masculinity of the gaze, the deadness of the feminine body, only to subvert and disturb the security of these stakes in cultural self-representation” (Bronfen 1992, 406). ${ }^{5}$

Whilst Bronfen, following Linda Hutcheon, identifies a hysteric strategy as one found primarily in contemporary, postmodern women's writing, I argue that we can identify the roots of such a strategy in Levy's and Barnes's various poetic representations of the deadwoman muse. In many ways, the dead woman serves as the ultimate embodiment of Levy's and Barnes’s complex ideas about gender, sexuality, desire, femininity, identity, authorship and otherness. As such, this aspect of their work, which has been largely neglected, deserves more critical attention than it has hitherto attracted. Such neglect may in part arise from the fact that the presence of the dead woman in Levy's and Barnes's poetic oeuvre, when it has been noted, has been read as highly problematic. For example, in her foundational survey of lesbian literature, Surpassing the Love of Men (1981), Lillian Faderman laments that Barnes apparently internalized decadent male writers’ negative portrayal of lesbianism (Faderman 1985, 364). ${ }^{6}$ Levy has also been criticized for drawing connections between female

\footnotetext{
${ }^{5}$ Joyce Zonana also addresses this question in relation to Aurora Leigh, arguing that Barrett-Browning presents Aurora as a living 'embodied muse' who incorporates the 'masks' of womanhood into herself, uniting 'spirit and flesh, heavenly and earthly' (1989, 251).

${ }^{6}$ Faderman writes: "Djuna Barnes seems to have internalized the literary images of lesbianism ... although she did not let them lead to death” $(1985,364)$. Faderman argues that the lesbian poet Renée
} 
homoerotic desire and death. ${ }^{7}$ For critics, there is perhaps something embarrassing (if not dangerous) in these women poets' clinging to a trope irredeemably associated with the maleorientated poetic traditions that cast woman as a dead object, rather than an active creator. Moving on from this critical position, I will illustrate that whilst Levy and Barnes consistently draw on the tradition of the dead-woman muse—and draw on it in ways that are disturbing, challenging and riven with ambivalence — they also reimagine this trope for their own ends. Their verse parodies masculine conventions and imbues their portrayal of the dead woman with a sense of female subjectivity and homoerotic desire. Rather than rejecting them as politically insanitary, we can benefit from looking in detail at Levy's and Barnes’s representations of the dead-woman muse.

Despite the differences in the representation of the dead-woman muse briefly mentioned above-Levy's wispy apparition; Barnes's earthy corpse—I propose that in both Levy's and Barnes's poetic oeuvres, the dead woman serves two purposes. The first is to reveal the ways in which women were both empowered and endangered by their increasing access to, and visibility within, urban city spaces in the late nineteenth- and early-twentieth century. The second is to establish how female homoerotic desire (and nascent queer identity) is subtly encoded through the trope of the apparitional lesbian: a concept theorized by Terry Castle (1993). Read together, Levy's and Barnes’s depictions of the dead-woman muse therefore reveal much about the changing position of women and emerging constructions of homosexuality in the late nineteenth and early twentieth century, particularly in the context of the increasingly modernized urban environments that both poets inhabited.

\section{Suicide in the City: The New Woman, Transportation and Dangerous Urban Economies}

Vivien's internalization of decadent influence literally contributed to her death (a result of anorexia, alcoholism and drinking eau de cologne).

${ }^{7}$ For example, Emma Francis draws a link between “In the Mile End Road” and Jack the Ripper's murders (see p. 12 of this essay). 
In her final volume, A London Plane-Tree, and Other Verse (1889), Levy is primarily inspired by urban scenes, portraying women as confident traversers of the city space. For example, in "Ballade of an Omnibus," the speaker is a female passenger who gleefully relates how:

The city pageant, early and late

Unfolds itself, rolls by, to be

A pleasure deep and delicate.

An omnibus suffices me. $(1889,22)$

Critics such as Ana Parejo Vadillo have read this volume of Levy's poems as voicing the "new public woman" of the late nineteenth century: an increasingly visible and independent public woman emerging as a regular presence on public transport, or on foot, confidently traversing the city streets. This figure came to be linked with the many images of the "New Woman” which were circulating in art and literature at that time (such as Grant Allen's The Woman Who Did [1895] and New Woman fiction by Sarah Grand, George Egerton and Mona Caird). Indeed, as Deborah Parsons notes, “urbanness” was one of the hallmarks of the New Woman: “[a]s both social figure and literary caricature, she was a specifically urban character, the result of the circumstances and qualities of a growing metropolitan society” (Parsons 2000, 82-3). Previously, the term “public woman" denoted a fallen woman or prostitute, forced to live by her wits and display herself as a commodity to the roving eye of the male flâneur. The increasing presence of women in the city led to a shift in the meaning of the term "public woman," and thus to a transformation of the signification of this figure in literature. As Lynda Nead notes, by the 1860s, even unaccompanied, middle-class women were publically present in the city, challenging rigid notions of the 'separate spheres' (2000, 67). As growing numbers of independent women employed as shop-girls, secretaries, post office clerks, dress-makers and typists, moved around the city, the "public woman” lost her stigma and instead became associated with modernity and the hastening pace of urban life. 


\section{Parker 9}

Amy Levy, who was born in Clapham and later moved with her family to Endsleigh Gardens, Bloomsbury, was particularly inspired by the possibilities of the urban environment opening up to women at this time: “[f]or Levy ... writing the city, writing London, marked a sense of exciting newness, of poetic self-discovery and presence” (Vadillo 2005, 57). For example, the title poem in Levy's final volume A London Plane-Tree (1889) neatly aligns the female poet with the city-scene, observing from her garret window the plane-tree which "loves the town":

Green is the plane-tree in the square,

The other trees are brown;

They droop and pine for country air;

The plane-tree loves the town.

Here from my garret-pane, I mark

The plane-tree bud and blow,

Shed her recuperative bark,

And spread her shade below. (“A London Plane Tree” 1889, 17)

Several critics have linked Levy's enthusiastic celebration of the city to her status both as a Jew and a woman; Alex Goody in particular notes that “[a]s an independent late nineteenth-century woman and a Jew, Levy has a double affinity with the urban space as the 'paven ground' for her subjectivity” (2010, 161). Indeed, with increasing numbers of Jews occupying London during the late nineteenth-century, city life and Jewish identity were often linked. This was partly due to a wave of immigration from Eastern Europe in the 1880s, which proved troubling to assimilated Jews already living in London: "the new immigrant 'ghettos' were both an embarrassment and a threat, with the potential, it was believed, to undo the social and political gains made by anglicized Jews” (Endelman 2002, 171-72). Levy herself frequently expressed the view that the Jew was "quintessentially an urban creature" (Hunt Beckman 2000, 124); for example, in her essay “Jewish Children” (1886) she describes the Jewish child as the "descendant of many city-bred ancestors” (1993, 530). It is the cultural 
trope of the "Wandering Jew" that connects Jewish identity with a nomadic, unfixed urban existence. ${ }^{8}$ Though such "wandering” carries connotations of exile and diasporic identity, it might also suggest the freedom of the urban traveller.

Therefore Levy's gender and Jewish identity enabled her to make the crucial move from passante to flâneur. As Parsons notes, for male writers such as Charles Baudelaire, the "urban muse was consistently the female figure of the prostitute/passante" (2000, 89). She was observed by the male gaze and transformed in male-authored poetry into an alluring figure that combined the ephemerality of modern life, male freedom and (a hint of) sexual danger. Levy, in contrast, "is one of the first women writers to consistently adopt the perspective of the female writer-observer or flâneur" (Parsons 2000, 87). Vadillo argues that Levy achieves this by reimagining the poet as a passenger:

for Levy, the figure of the passenger had important social and political implications because it was as passengers, she argued, that women poets could become spectators of modern life, challenging masculinist representations of women in the modern metropolis, and transgressing the incarcerating ideology of the private/public spheres. $(2005,40)$

Transportation played a key role in establishing the writer-observer's flâneur-like inspection of urban life. In particular, the omnibus enabled women to travel on top and in the open air, looking down upon the city they were moving through. While such a highly-visible mode of transportation might attract censure (depending on one's social class), crucially, the omnibus "allowed the woman of the 1880s and 1890s to move in and observe the city without threat on the streets” (Parsons 2000, 97). ${ }^{9}$

In "Ballade of an Omnibus," we can see how adopting this position of observation enables Levy’s speaker to harness poetic identity and become one with the city:

The 'busmen know me and my lyre,

\footnotetext{
${ }^{8}$ The legend of the Wandering Jew originates in the thirteenth-century manuscript Flores Historiarum by Roger of Wendover. After taunting Jesus during the crucifixion, the Jew is cursed to wander the earth until the Second Coming. For a history of developments of this legend, see Cohen (2007).

${ }^{9}$ See Amy Levy's novel, The Romance of a Shop (1888), in which the heroine Gertrude, riding on the top of the omnibus, is met with "a look of speechless horror" from her well-to-do aunt $(1993,105)$.
} 
From Brompton to the Bull-and-Gate.

When summer comes, I mount in state

The topmost summit, whence I see

Croesus look on, compassionate-

An omnibus suffices me. $(1889,21)$

Through the prism of Greek mythology, Levy’s speaker adopts a Vatic persona, depicting herself as an Orpheus-like figure, whose poetic skill raises her above "Croesus" (the name of a Lydian king famed for his wealth). Noting that "men to carriages aspire” $(1889,21)$, the poem makes clear that whilst the omnibus admits passengers of all classes, it literally and metaphorically elevates the female passenger by granting her a privileged perspective. Vadillo argues that mass transport "thus emerges in the work of Amy Levy as the key element in the reconfiguration of race, gender and class in the everyday life of the city” $(2005,72)$.

Despite its apparently "levelling” effect, critics such as Goody contend that "the inbetween urban space, is not simply positive and enabling” (2010, 166). Levy's poems also hint at the dangers for women inhabiting the city space, by invoking the image of a female spectre: a motif which reappears in several poems throughout A London Plane-Tree and Other Verse. Perhaps the most famous of these is "In the Mile End Road”:

How like her! But 'tis she herself, Comes up the crowded street, How little did I think, the morn, My only love to meet!

Whose else that motion and that mien?

Whose else that airy tread?

For one strange moment I forgot

My only love was dead. $(1889,50)$

The title of this poem locates this ghostly encounter specifically in London's East End, an area populated by Jewish immigrants during the late nineteenth-century. It also recalls Jack 
the Ripper's Whitechapel murders of $1888 .^{10}$ Therefore, the woman at the heart of the poem might well be interpreted as a street-walking woman/prostitute, or conversely, as an independent New Woman. This woman has clearly “passed on,” but remains as an apparition, walking the streets. In contrast to "Ballade on an Omnibus” or "A London Plane-Tree,” the speaker in this poem is not a city-dwelling woman herself, but is more closely aligned with the (traditionally) male flâneur who observes the "passing” woman in the street. Emma Francis even draws a link between the deceased woman of Levy's poem and Jack the Ripper’s murders: “[a] poem published in 1889 which describes an erotic fixation upon the ghost of a street walking woman cannot but be read as dealing, at least in part, with the Whitechapel murders of 1888 . . . Levy has produced a poem in which the voice of the lover and perhaps of the lesbian is concurrent and interchangeable with the voice of the Ripper” (1999, 200-201).

Goody suggests that the speaker of the poem is aligned with Jack the Ripper (who was believed by many to be Jewish) and asserts that "[a]t some level in this poem, the evil Jewish murderer stalks the streets and dispenses with the unsettling presence of the urban woman” $(2010,174) .{ }^{11}$ In this sense, one could argue that the poem embodies Levy's sense of an irrevocably split identity; one "side" of her identity destroys the other. Whether we interpret the poem's speaker as linked to Jack the Ripper or not, “In the Mile End Road” certainly hints at the dangers for women occupying the "crowded street[s].” In this way, the poem acts as a counterbalance to poems such as "Ballade of an Omnibus," since it implies that the urban woman's liberation could potentially be "the cause of her own destruction" (Goody 2010, 175). Removed from the protective environment of the omnibus, the female

\footnotetext{
${ }^{10}$ This locale appears in another poem, "Ballad of a Special Edition”, in which a newspaper seller spreads cries of "slaughter, theft, and suicide" in the East End: "He tramps the town from end to end. / How often we have heard it cried_ / A double murder in Mile End” (1889, 23).

${ }^{11}$ As Sander L. Gilman explains, the popular image of Jack the Ripper in the press was 'a caricature of the Eastern Jew' (1991, 113), playing on anti-Semitic prejudices (aggravated by the wave of recent Jewish immigration to the East End) and suspicion surrounding ritual slaughter of animals and circumcision: 'Jack the Ripper evoked in the minds of many the image of a foreign, syphilitic, mutilated butcher-Jew’ (1991, 119).
} 
spectre here hints that the woman who traverses London's thoroughfares on foot may meet a deadly fate.

Twenty-six years after the publication of Levy’s A London Plane-Tree, Djuna Barnes took up the role of flâneur in her first poetic collection, The Book of Repulsive Women (1915). Unlike Levy, whose verse is set in London, Barnes’s poems lead the reader through a specific New York geography. Some of the poems in The Book of Repulsive Women are entitled after particular areas of the city (“From Fifth Avenue Up”; “From Third Avenue On”). Recalling Levy's omnibus, Barnes's poetics of movement directs the reader through the city-space. This is implied by the title of one of her poems: "Seen from the ' $L$ "” (The " $L$ " refers to the elevated train-line which formed part of the New York City subway system, travelling between Manhattan and Brooklyn.) Barnes uses this modern form of transportation in a similar way to Levy’s omnibus, utilising the "L" as a "locomotive site of spectatorship" (Hardie 2005, 129). From this vantage-point, the speaker of "Seen from the 'L"' observes a nude woman standing at her window:

So she stands—-nude—-stretching dully

Two amber combs loll through her hair

A vague molested carpet pitches

Down the dusty length of stair.

She does not see, she does not care

It's always there.

The frail mosaic on her window

Facing starkly toward the street

Is scribbled there by tipsy sparrows-

Etched there with their rocking feet.

Is fashioned too, by every beat

Of shirt and sheet. $(2005,49)$ 
The poem functions as a vignette, offering a brief glimpse of a down-at-heel woman languidly beginning (or ending) her day. The " $\mathrm{L}$ " of the title therefore offers the speaker-and the reader-a voyeuristic glimpse of this woman's domestic interior and her naked body. A sense of the brevity of this moment is produced by the short final line of each stanza, and the rhyming couplet which concludes it, replicating the sense of rushing onward through various urban scenes, each impression quickly tailing off into another. This sense of falling away or unravelling occurs throughout the poem—-for example, in the description of the woman:

Raveling grandly into vice

Dropping crooked into rhyme.

Slipping through the stitch of virtue, Into crime. (49)

Several of Barnes’s poems encode the risks for women inhabiting these city spaces. In many poems, we are compelled to see that the freedom associated with the "modern girl" or "girl about town" in fact masks a sordid, exploitative reality. In these poems, Barnes implies that to prosper—or indeed to survive—in such a fast-paced urban environment, a young woman must construct herself as a commodity on the market. Either as a dancer, a singer, an office employee, or a prostitute, her livelihood depends on attracting and securing the male gaze. The effort and exhaustion of soliciting this gaze leads to a destructive, enervating cycle that is difficult to break. This trajectory is illustrated particularly well in a poem entitled “To a Cabaret Dancer.” This poem portrays a carefree young woman who comes to the city in search of entertainment, and potentially fame and romance. However, she quickly becomes jaded by the limited pleasures and opportunities that the city has to offer:

She came with laughter wide and calm;

And splendid grace;

And looked between the lights and wine For one fine face. 
And found life only passion wide

'Twixt mouth and wine.

She ceased to search, and growing wise

Became less fine.

Alienated by the fleeting encounters and lack of intimacy that characterize urban relationships, the woman degrades into a washed-up performer in the seedy "cabaret” of the title. Since we observe her "as she groped and clung” about a man’s "neck" $(2005,53)$, it is implied that her employment is little more than a form of prostitution. However, the speaker-who uses the first person plural throughout, as if speaking collectively on behalf of the customers who scrutinize the dancer—suggests that some mysterious element within the woman remains untarnished and inaccessible:

Yet some wondrous thing within the mess

Was held in check-

One master chord we couldn't sound

For lost the keys,

Yet she hinted of it as she sang

Between our knees.

Eventually, the cruel "jibes" of the customers and the relentless pace of city-life, lead the woman to deteriorate further, until her acquaintances no longer recognize her as they pass her in the street:

We saw the crimson leave her cheeks

Flame in her eyes;

For when a woman lives in awful haste

A woman dies.

Barriers and heart both broken—dust 
Beneath her feet.

You've passed her forty times and sneered

Out in the street.

A thousand jibes had driven her

To this at last;

Till the ruined crimson of her lips

Grew vague and vast. (“To a Cabaret Dancer” 2005, 53-4)

The fate of the "cabaret dancer" is deliberately ambiguous. The reference to her presence "in the street" implies that she ends up homeless and destitute, and the description of her pale cheeks and "ruined crimson" lips suggest disease. The poem functions as a warning that women will struggle to survive economically in a relentless urban system that requires their constant circulation among men, the performance of femininity, and the repeated abnegation of subjectivity in the gaze of the male other. Living in the glare of this gaze, the woman is driven to increasingly desperate acts, and the final one, it is inferred, will be suicide. The phrase, "this at last,” (emphasis added) and the image of her mouth growing “vague and vast” gestures towards a violent, bloody end, fulfilling the poem’s prophecy that “when a woman lives in awful haste / A woman dies” (2005, 53). Her speaker evidently blames the city for this fate, claiming: "A thousand lights had smitten her / Into this thing” $(2005,53)$.

Barnes’s poem intimates that women's increased freedom and visibility within the city may lead to prostitution, rape and suicide, as women become commodities (their shelflife ever waning) within destructive, misogynistic urban economies. ${ }^{12}$ This trajectory is taken explicitly to its conclusion in the final poem of The Book of Repulsive Women, entitled "Suicide”. This poem consists of two stanzas, labelled "Corpse A” and “Corpse B.” Though

\footnotetext{
${ }^{12}$ For a related discussion of gendered economies in Jean Rhys’ novels, see Cynthia Port, “'Money, for the night is coming': Jean Rhys and the Gendered Economies of Aging.” Women: A Cultural Review 12.2 (2001): 204-217.
} 
following the exact same prosodic pattern (e.g. end rhymes, line lengths, stresses), the descriptions of the two female corpses are conspicuously different in tone; Corpse A is "brought . . . in,” Corpse B is given "hurried shoves this way / And that” $(2005,55)$. Corpse A is described using mystical, self-consciously "poetic" imagery: her "little bruisèd body like / A startled moon” $(2005,55)$. In contrast, Corpse B is described in strikingly bathetic terms: "She lay out listlessly like some small mug / Of beer gone flat” $(2005,55)$.

These descriptions of the two women, and the ironic parallels drawn between them, serve to emphasize the fact that, even in death (or, especially in death), women continue to circulate as commodities and aesthetic objects. To begin with, these women are literally commoditized in the sense that they are labelled as "Corpse A" or "B," rather than named as individuals. ${ }^{13}$ "Corpse B" is clearly a victim of city-life. Described as "shock-abbreviated / As a city cat” $(2005,55)$, she is bedraggled and physically-stunted as a result of the urban struggle for survival. The comparison to a "mug of beer” figures her as the unwanted “dregs" of the city, the punch-line of a tired joke.

Though more elegiac on the surface, the description of "Corpse A" also figures the female corpse as a commodity. The phrase "all the subtle symphonies of her" $(2005,55)$ employs the rhetoric of a fashion magazine, recalling the tone of Barnes's Vanity Fair article mentioned above. The comparison of the dead woman's body to “[a] twilight rune” represents the female corpse as an esoteric symbol to be decoded by the male gaze. While "Corpse B" is an unwanted by-product of the city and "Corpse A" is a poetical fragment, both are described as objects, as less than human. It may even be that these descriptions represent different accounts of the same woman, rather than two different women, demonstrating that a woman's death can be aestheticized in different ways: romanticized as poetical and tragic, or rendered mundane and insignificant. Thus, Barnes reveals how the female body has been relentlessly

\footnotetext{
${ }^{13}$ In this sense, we can observe parallels with Vernon Lee's "A Wedding Chest” which opens with an auction catalogue containing an entry for item "No.428": the panel from of a an Italian wedding coffer which was used to store (and circulate) the corpse of an abducted girl (page reference for Libidinal Lives).
} 
aestheticized, dehumanized and objectified. These dead women are commodities; wheeled in, assessed by the male gaze, and transformed into art, or cast aside, as mere fodder for the city.

\section{The Apparitional Lesbian and the Flowering Corpse}

Levy and Barnes use their dead-woman muses in various ways to encode female homoerotic desire. Indeed, “Love, Dreams, and Death,” (a section of Levy’s A London Plane-Tree) has attracted critical attention from those queer theorists interested in the apparitional beloveds that feature in these poems. These poems recount nightly visitations from airy spectres, which leave the waking speaker aching with longing. The persistent gender ambiguity of the speaker and the spectral visitor in these poems invites a homoerotic interpretation; the shared looks of desire between the speaker and the ghost, and the subtle fragrance that lingers on its departure encode these encounters as erotic, yet ultimately impossible, liaisons. This reading of Levy's poems reinforces Terry Castle’s path-breaking work in The Apparitional Lesbian (1993), which argues that ghostly tropes have been consistently invoked in order to "ward off" and dematerialize the threat posed by lesbian desire, and conversely, to enable the writing of female homoerotic desire. This apparitional metaphor has proved particularly effective as it enables an acknowledgment of homoerotic desire, whilst simultaneously disembodying that desire, rendering it less threatening:

The spectral figure is a perfect vehicle for conveying what must be called ... that 'recognition through negation' which has taken place with regard to female homosexuality in Western culture since the Enlightenment. Over the past three hundred years ... the metaphor has functioned as the necessary psychological and rhetorical means for objectifying — and ultimately embracing—-that which otherwise could not be acknowledged. (Castle 1993, 60)

However, I will invert Castle’s theoretical paradigm by suggesting that Barnes, by contrast, presents a startling re-embodiment of the dead woman as a "repulsive” corpse. In The Book of Repulsive Women and in several poems from A Book (1923), Barnes’s dead women pulse 
with life: their lustrous hair continues to grow, their corpses sprout flowers and weeds, they move and jerk about beneath the earth. ${ }^{14}$ I argue that this grotesque embodiment of the dead woman represents Barnes’s attempt to “re-flesh" the lesbian body and assert female homoerotic desire without the use of the spectralizing metaphors that we find in Levy's work. If we begin, then, with Levy, it is noteworthy that of the seventeen poems of which her "Love, Dreams, and Death" is composed at least nine treat the theme of a dead/ghostly beloved. This focus on the apparitional muse commences with the fourth poem in the sequence, entitled “The Dream” (1889, 38). Carrying the epigraph ("Believe me, this was true last night, / Tho' it is false to-day, a quotation taken from A. M[ary]. F. Robinson’s poem 'Paradise Fancies' (1878) ${ }^{15}$ this poem begins with the speaker recounting a ghostly visitation experienced the night before:

A fair dream to my chamber flew:

Such a crowd of folk that stirred,

Jested, fluttered; only you,

You alone of all that band,

Calm and silent, spake no word.

Only once you neared my place,

And your hand one moment’s space

Sought the fingers of my hand;

Your eyes flashed to mine; I knew

All was well between us two. $(1889,38)$

\footnotetext{
${ }^{14}$ In this sense, Barnes draws particularly on Baudelaire's experiments with the aesthetics of the corpse, such as in 'Une Charogne' (A Carcass) which observes the perverse beauty of the rotting carcass and imagines the beloved 'under blossoming grass, / As you moulder with bones of the dead' $(1998,63)$. The title of Barnes’s ‘The Flowering Corpse' invokes Baudelaire’s Les Fleurs du Mal, but she adapts his portrayal of the corpse from a 'lecherous whore, / sweating out poisonous fumes' (59) to a more positive image of a body that nourishes the earth.

${ }^{15}$ Robinson's poem appears in her debut volume A Handful of Honeysuckle (1878). Interestingly, before her marriage to James Darmesteter in 1888, Robinson was involved in a romantic friendship with the writer Vernon Lee. Levy met Lee in 1886 and became infatuated with her - perhaps a factor that influenced her choice of an epigram from Robinson.
} 
Here, the ghost represents a familiar figure in the speaker's life, perhaps even a deceased companion. It is unclear, though, whether the phantasm represents a living or dead individual, and this is further complicated by another ambiguity: the gender of the speaking subject and the apparition, which remains unspecified throughout. This leaves the precise nature of the desire at the heart of the poem unresolved.

In the concluding section of the poem, the speaker awakes at dawn, still curiously affected by the dream, which lingers in their mind like a sweet scent: "The fair dream hovered round me, clung / To my thought like faint perfume” $(1889,38)$. Francis argues that this imagery of perfume flasks and "string[s]/ Of amber" $(1889,38)$ encodes the spirit as female: "The awakened speaker represents the residue the ghost leaves behind as a litter of cosmetics and decorations used in the production of femininity” $(1999,191)$. The next poem in the sequence, entitled "On the Threshold" $(1889,39)$ may be read as a continuation of the theme of the dead beloved. Again the (ambiguously-gendered) speaker narrates a dream in which the beloved appears dead: "garlanded / With blooms of waxen whiteness" (1889, 39), suggestive of bridal apparel. A later poem of the sequence, “In the Night,” confirms the feminine identity of the beloved and continues the narrative of her death:

What ails my love; what ails her? She is paling;

Faint grows her face, and slowly seems to fade!

I cannot clasp her-stretch out unavailing

My arms across the silence and the shade. $(1889,41)$

It becomes clear, then, that the shadowy figure that visits the speaker nightly in dreams represents the ghost of a dead female beloved. Crucially, she appears at liminal times, such as twilight and dawn, when, according to folkloric beliefs, the boundary between the two worlds 
is thin. ${ }^{16}$ This "in-between” state is described in "Borderland”: “Am I waking, am I sleeping? / As the first faint dawn comes creeping / Thro’ the pane” $(1889,42)$.

The persistent presence of the ghostly muse in these love lyrics has been analysed in light of Levy’s apparently homoerotic inclinations. Levy’s biographer Linda Hunt Beckman asserts that "Levy was a woman whose desire was homoerotic" (2000, 7), citing evidence of numerous homoerotic attachments throughout Levy’s life, from letters that recount her youthful adoration for her school teacher, Miss Edith Creak, to her friendship with Vernon Lee, described in the poem “To Vernon Lee” (1889). ${ }^{17}$ Whilst Melvyn New and Deborah Epstein Nord interpret her love lyrics as voiced by a male persona, numerous poems from Levy’s oeuvre, including “Sinfonia Eroica," “In a Minor Key” and “To Lallie” can be analysed as evidence of Levy’s homoerotic attachments. ${ }^{18}$

As I point out, Levy's decision to represent homoerotic desire using spectral metaphors can be explained using Castle’s theory of the “apparitional lesbian.” For Levy, the spectral metaphor enables her to write about communion with same-sex lovers, describing a desire that would perhaps not be permissible in more explicit terms. Semi-conscious states and dreams, for example, offer a space where possibilities can be realized, that would be condemned in waking life. ${ }^{19}$ In this sense, Levy uses liminal states and spectres in a similar way to the "fantasias" constructed by late-Victorian female aesthetes. Talia Schaffer argues that such non-realist modes and "phantasmatic diction” permitted female aesthetes to write about “new sorts of gender politics. Writers situated a woman's desires in the unreal space of 'dream' and 'fantasy,' thereby preventing the reader from criticizing the character according to everyday nineteenth-century sexual norms” (Schaffer 2000, 51). Levy therefore makes use of the very strategy by which homoerotically-inclined women were "ghosted” in Victorian

\footnotetext{
${ }^{16}$ Twilight also has lesbian connotations - seen, for example, in the title of a 1964 lesbian pulp novel Twilight Lovers (see Faderman 1991).

${ }^{17}$ See Amy Levy's Letter 8, reprinted in Hunt Beckman (2000, 223-225). It is interesting to note that Levy uses a quotation from A. Mary F. Robinson - the former lover of Vernon Lee - to signal her own homoerotic desire.

${ }^{18}$ See Deborah Epstein Nord (1990, 748) and Melvyn New (1993, 38). See also Linda Hunt Beckman’s analysis of Levy's homoerotic poems (2000, 87-91).

${ }^{19}$ For example, see Sheridan Le Fanu’s “Carmilla” (1872) in which strange dreams, somnambulism and vampirism provide metaphors for lesbian desire.
} 
literary representations; that is to say, dematerialised in order to invoke an elusive yet persistently haunting female homoerotic desire. In this sense Levy anticipates some of the twentieth-century lesbian writers that Castle suggests harness the spectral metaphor. "Used imaginatively," Castle remarks, "the very trope that evaporates can also solidify” and it does so through the persistent haunting power of lesbian desire (1993, 46-7).

A “solidifying” of the spectral metaphor is also seen in Barnes’s work. But here, the beloved is less a ghost, more a corpse. Rebecca Loncraine argues that Barnes's association of lesbian love with death functions as both: "a commentary on the 'unthinkableness', in Victorian terms, of lesbian love” and a defiant resurrection of the lesbian: "the socially abjected, figured as the 'repulsive’ corpse” (Loncraine 2003, 42). I therefore propose that Barnes's striking embodiment of the dead woman reflects a desire to "re-flesh" the lesbian body and articulate female homoerotic desire without spectral metaphors.

Barnes's series of poems about a dead beloved were published in her second collection, A Book (1923). Gillian Hanscombe and Virginia L. Smyers argue that eleven of these poems can be read as the story of Barnes’s love for a woman named Mary Pyne: “[a]mong the collection’s 20 poems, 11 can be sequentially read as the story of Djuna’s love for Mary Pyne who’d died in 1915” $(1987,234)$. Pyne was a member of the Provincetown Players, a New York theatre group to which Barnes also belonged during the period 19151918. Hanscombe and Smyers suggest that The Book of Repulsive Women was written at around the same time that Barnes fell in love with Pyne, thus the poems may have been indirectly inspired by her $(1987,89)$. Pyne certainly lived the kind of brief, tragic life described in The Book of Repulsive Women: she lived in poverty, supporting herself and her father by working as a cashier, dancehall instructor, waitress and actress.

In 1915, Pyne married Harry Kemp, a fellow Provincetown player who styled himself as “the vagabond poet.” In 1919, she contracted tuberculosis. Barnes nursed Pyne until her death, writing to her male lover Courtenay Lemon that: "Mary has been given up by 2 nurses, 2 doctors \& a score of others at least 10 days back, but she still breaths [sic] - lies on her left side for the first time \& is living on oxygen” (qtd. Hanscombe and Smyers 1987, 90). Pyne 
died in November 1919, aged 25. Barnes’s biographer Phillip Herring writes that Barnes tried to claim the body but was refused because she had no money $(1995,74)$ —an anecdote that quite literally underlines the connections between death, economics and female disenfranchisement. Barnes's grief over Mary Pyne continued to haunt her; Herring cites the painter Maurice Sterne who remembers Barnes "grieving over the death of this 'Titian-haired beauty' ... 'sobbing painfully, her head buried in her arms, saying over and over that she would never get over the loss ...'” (qtd. Herring 1995, 74).

Of the several poems in A Book that can be related to this doomed love affair, a poem entitled "Six Songs of Khalidine” is perhaps the most striking. Published in 1923, but written in 1919, it is dedicated “To the Memory of Mary Pyne," and describes a bedside vigil beside a red-haired beloved:

The flame of your red hair does crawl and creep

Upon your body that denies the gloom

And feeds upon your flesh as 'twould consume

The cold precision of your austere sleep-

And all night long I beat it back, and weep. $(2005,86)$

Lillian Faderman singles out “Six Songs of Khalidine,” with its grim scenario and gothic motifs, as a particularly objectionable example of Barnes’s Decadent influence: “the beloved's red hair flames and crawls and creeps, as in Verlaine's lesbian poems. Her fallen lids are stained with ebony ... the setting comes directly out of nineteenth-century French novels of decadence” (Faderman 1985, 364). But Barnes’s poem perhaps shares more similarities with the work of Charles Baudelaire and Algernon Charles Swinburne, in particular Swinburne’s “The Leper” (2004, 113-117). “The Leper,” published in Swinburne’s controversial 1866 collection Poems and Ballads, takes the form of a dramatic monologue spoken by a "poor scribe” who suffers with obsessive love for a deceased woman. This woman scorned the speaker when she was alive but then grew to rely on him as she succumbed to disease. He hides her away with him and, once she has died, stays with her dead body, fixating on her decaying beauty, particularly her hair: 
Yet am I glad to have her dead

Here in this wretched wattled house

Where I can kiss her eyes and head.

Six months, and I sit still and hold

In two cold palms her cold two feet.

Her hair, half grey half ruined gold,

Thrills me and burns me in kissing it. (“The Leper” 2004, 113-116)

Hair is similarly fetishized in Barnes's poem, where the beloved's red hair takes on a life of its own, and threatens to consume her weak body like a purging fire. ${ }^{20}$

Barnes’s “Six Songs of Khalidine” and many other poems in A Book, focus on the uncanny vitality and eroticism of the dying and dead woman's body. In "Song in Autumn," for instance, the beloved feeds the "green / Long grasses” $(2005,88)$ and in "The Flowering Corpse," "Soft hairs blow" above her head and her "armpits bloom” (2005, 91). The uncanny vitality of the dead woman links to a popular myth surrounding the Pre-Raphaelite muse, Elizabeth Siddal. As the story goes, in 1869, Dante Gabriel Rossetti disinterred Siddal's body in order to retrieve the poems he had buried with her—only to find her coffin filled with a profusion of red-gold hair that had kept on growing after death. ${ }^{21}$ Deborah Tyler-Bennett has pointed out that Barnes's portrayal of Mary Pyne engages with this by-then familiar public legend, placing Pyne in a pantheon of tubercular beloveds alongside Siddal and Edgar Allen Poe’s gothic maidens. Tyler-Bennett argues that Barnes uses the Gothic mode to selfconsciously question the ways in which women like Pyne and Siddal were, through their unearthly beauty and early deaths, fated to become static and unchanging products of the male imagination. She writes that Barnes “recognised how Pyne’s ‘Greenwich Village Beauty’ status obliterated every other aspect of her personality” (Tyler-Bennett 2001, 99). Rather than endorsing the archetype of the tragic, red-haired beauty, Barnes uses it to indicate its

\footnotetext{
${ }^{20}$ The poem also owes a debt to Robert Browning's 'Gold Hair: A Story of Pornic' (1864) and 'Porphyria's Lover' (1842).

${ }^{21}$ See Jan Marsh, The Legend of Elizabeth Siddal. London: Quartet Books, 2010.
} 
limitations to the reader: her dead-woman muses constantly evade their living lovers; they are "hidden" beneath the earth, where their lovers cannot reach them.

In H.D. and the Victorian Fin de Siècle (1996), Cassandra Laity reveals that the modernist poet H.D. was particularly inspired by Elizabeth Siddal, who she felt had a grotesque beauty that could not be contained by the Pre-Raphaelite portraits in which she was represented. H.D. also idolized Greta Garbo for the same reason: “[b]oth women were considered to be sirens, of unconventional, larger-than-life beauty . . . in possession of an intensity that radiated beyond the frame (celluloid or picture) of the male gaze” (Laity 1996, 144). ${ }^{22}$ Therefore, if, as Loncraine argues, Barnes disinters the "repulsive" abject body of the lesbian in order to resurrect her, she perhaps also does so in order to suggest the impossibility of ever "capturing” this body in a fixed, stable representation. Barnes emphasizes the perverse vitality of the flowering corpse, envisioning Pyne’s body as feeding nature, while beneath the soil her armpits bloom with "passion flowers” (“The Flowering Corpse” 2005, 91). This fertile, sprouting corpse disrupts and inverts the boundary between life and death, suggesting that however much one might seek to represent a woman, by killing her into art, she still exceeds such representation - she decomposes herself. Similarly, Daniela Caselli has noted that while Barnes’s illustrations borrow Aubrey Beardsley’s decadent black-and-white aesthetic, they do so only to disable it by blurring the neatness of the lines so that the colours "seep into one another and present the human form ... on the verge of dissolution” (2009, 76).

In representing the lesbian body as a perverse corpse that evades fixed representation, Barnes may be reacting to the increasing categorization and pathologisation of the homosexual in the early twentieth century. During this period, definitions of sexual “deviation” and perversity proliferated via the works of sexologists and psychoanalysts such

\footnotetext{
${ }^{22}$ Castle’s Apparitional Lesbian in fact begins with the ghost of Garbo: 'One of the several ghosts haunting this book is that of Greta Garbo, who died in April 1990, just after I'd started working on the volume’s signature piece, “The Apparitional Lesbian”' $(1993,1)$.
} 
as Havelock Ellis, Richard Freiherr von Krafft-Ebing and Sigmund Freud. ${ }^{23}$ These emerging sexological and psychoanalytical discourses presented problems as well as opportunities for homoerotically-inclined individuals; they provided a language to express, but also to define and control genders and sexualities "outside of" heterosexuality (as Michel Foucault most famously argued in The History of Sexuality). ${ }^{24}$ Therefore, whilst critics such as Faderman, Herring and others have read Barnes's The Book of Repulsive Women as straightforwardly and audaciously presenting "lesbians" to the reader (for perhaps the first time), Caselli argues that Barnes "resists the spectacularization of 'the' lesbian ... and a revelation of the lesbian 'for who she is'” (2009, 77), arguing that whilst some poems in the volume undoubtedly lend themselves to being read as staging the birth of the lesbian; this ... is a difficult birth, which does not necessarily lead to lineage, but uses this 'repulsive' womanhood as the measure of a possible disruption of genealogy. $(2009,77)$

We can detect a similar refusal to define or construct the lesbian in Levy's work. For example, Francis argues that in Levy's later poetry “subjectivities and forms of experience ... become increasingly less locatable, less intelligible within conventional accounts of sexual and social identification” $(1999,196)$. The poems of “Love, Dreams, and Death” sequence, with their ambiguous descriptions of dream-like states, liminal "borderlands," ungendered speakers and disembodied encounters with feminine apparitions who may be alive or dead, invoke the spectre of the dead-woman muse as a way of expressing homoerotic desire, while radically questioning the fixed categories of both desire and gender. Francis finds such a disruption disturbing: "[t]hese poems are profoundly discomforting in the way they describe the breakdown of all possibilities of limitation or structuration, and the most significant casualty of this battle is sexual difference itself” $(1999,197)$.

\footnotetext{
${ }^{23}$ See Krafft-Ebing's Psychopathia Sexualis (1886); Ellis, Sexual Inversion (1897) and Freud, The Interpretation of Dreams (1900) and Three Essays on Sexuality (1905).

${ }^{24}$ Foucault describes the 'scientia sexualis' (science of sexuality) of the nineteenth-century as 'a proliferation of discourses, carefully tailored to the requirements of power; the solidification of the sexual mosaic $[\ldots]$ the mandatory production of confessions and the subsequent establishment of a system of legitimate knowledge and of an economy of manifold pleasures' $(1990,72)$.
} 
Therefore, in both Levy's and Barnes’s work, the dead-woman muse serves as the embodiment of a number of challenging contradictions regarding gender, desire and identity. In this sense, this muse is a figure that cuts across the major themes found in both their oeuvres. The dead woman signifies both the opportunities and dangers for women inhabiting the city space in the late nineteenth-century; her new-found freedom to traverse the streets, and yet her dangerous circulation in a misogynistic system that still views women as consumable, replaceable objects. This dead woman also represents the apparitional lesbian: a figure for both the invisibility and persistence of female homoerotic desire. Finally, her body, resurrected as a "repulsive corpse" delineates the aspects of female subjectivity and sexuality that escape categorization or containment. Read together, Levy's and Barnes's depictions of the dead woman therefore reveal the opportunities and dangers offered by the spectral metaphor; this trope that risks connecting lesbian desire pejoratively to death, destruction and perversity also has the power to re-flesh a corpse. 


\section{Works Cited}

Bergland, Renée L. 2000. The National Uncanny: Indian Ghosts and American Subjects. Hanover, New Hampshire: University Press of New England. Print.

Bronfen, Elisabeth. 1992. Over Her Dead Body: Death, Femininity and the Aesthetic. Manchester: Manchester University Press. Print.

Caselli, Daniela. 2009. Improper Modernism: Djuna Barnes’ Bewildering Corpus. Farnham, Surrey: Ashgate. Print.

Castle, Terry. 1993. The Apparitional Lesbian: Female Homosexuality and Modern Culture. New York: Columbia University Press. Print.

Cohen, Richard I. 2007. “The 'Wandering Jew' from Medieval Legend to Modern Metaphor.” In The Art of Being Jewish in Modern Times. Ed. Barbara KirshenblattGimblett and Jonathan Karp, 147-175. Philadelphia: University of Pennsylvania Press. Print.

Barnes, Djuna. 2005. “To a Cabaret Dancer.” [1915] In Djuna Barnes: Collected Poems With Notes toward the Memoirs. Ed. Phillip Herring and Osías Stutman, 53-54. Wisconsin: University of Wisconsin Press. Print.

---. 2005. “The Flowering Corpse.” [1923] In Djuna Barnes: Collected Poems With Notes toward the Memoirs. Ed. Phillip Herring and Osías Stutman, 91. Wisconsin: University of Wisconsin Press. Print.

--- .2005. “Seen from the 'L'” [1915] In Djuna Barnes: Collected Poems With Notes toward the Memoirs. Ed. Phillip Herring and Osías Stutman, 49. Wisconsin: University of Wisconsin Press. Print.

--- .2005. “Six Songs of Khalidine.” In Djuna Barnes: Collected Poems With Notes toward the Memoirs. Ed. Phillip Herring and Osías Stutman, 86-87. Wisconsin: University of Wisconsin Press. Print.

--- . 2005. "Suicide.” [1915] In Djuna Barnes: Collected Poems With Notes toward the Memoirs. Ed. Phillip Herring and Osías Stutman, 55. Wisconsin: University of Wisconsin Press. Print.

Baudelaire, Charles. 1998. 'Une Charogne.' [A Carcass, 1857] In The Flowers of Evil. Trans. James McGowan, introduced by Jonathan Culler, 59-63. Oxford: Oxford University Press. Print.

Endelman, Todd M. 2002. The Jews of Britain: 1656 to 2000. California: University of California Press. Print.

Epstein Nord, Deborah. 1990. “'Neither Pairs Nor Odd’: Female Community in Late Nineteenth-Century London.” Signs 15 (4): 733-754. Print.

Faderman, Lillian. 1985. Surpassing the Love of Men: Romantic Friendship and Love between Women from the Renaissance to the Present. London: The Women’s Press. Print.

---. 1991. Odd Girls and Twilight Lovers: A History of Lesbian Life in Twentieth-Century America. New York: Columbia University Press. Print. 
Foucault, Michel. 1990. The History of Sexuality. Volume 1: An Introduction [1976]. New York: Vintage. Print.

Francis, Emma. 1999. “Amy Levy: Contradictions?_Feminism and Semitic Discourse.” In Women's Poetry, Late-Romantic to Late-Victorian: Gender and Genre, 1830-1900. Ed. Isobel Armstrong and Virginia Blain, 183-204. London: Palgrave. Print.

Gilman, Sander L. 1991. The Jew’s Body. New York: Routledge. Print.

Goody, Alex. 2010. "Passing in the City: The Liminal Spaces of Amy Levy’s Late Work.” In Amy Levy: Critical Essays. Ed. Nadia Valman and Naomi Hetherington, 157-179. Ohio: Ohio University Press. Print.

Hanscombe, Gillian and Virginia L. Smyers. 1987. Writing For Their Lives: The Modernist Women, 1900-1940. London: The Women’s Press. Print.

Hardie, Melissa Jane. 2005. “Repulsive Modernism: Djuna Barnes’ The Book of Repulsive Women.” Journal of Modern Literature 29 (1): 118-132. Print.

Herring, Phillip. 1995. Djuna: The Life and Work of Djuna Barnes. London: Penguin. Print.

---, and Osías Stutman Ed. 2005. Djuna Barnes: Collected Poems With Notes toward the Memoirs. Wisconsin: University of Wisconsin Press. Print.

Hunt Beckman, Linda. 2000. Amy Levy: Her Life and Letters. Ohio: Ohio University Press. Print.

Laity, Cassandra. 1996. H.D. and the Victorian Fin de Siècle: Gender, Modernism, Decadence. Cambridge: Cambridge University Press. Print.

Levy, Amy. 1889. “Ballade of an Omnibus.” A London Plane-Tree, and Other Verse, 21-22. London: T. Fisher Unwin. Print.

---. 1889. “Borderland.” A London Plane-Tree, and Other Verse, 42. London: T. Fisher Unwin. Print.

---. 1889. “The Dream.” A London Plane-Tree, and Other Verse, 38. London: T. Fisher Unwin. Print.

---. 1889. “In the Mile End.” A London Plane-Tree, and Other Verse, 50. London: T. Fisher Unwin. Print.

---. 1889. “A London Plane-Tree.” A London Plane-Tree, and Other Verse, 17. London: T. Fisher Unwin. Print.

---. 1889. “On the Threshold.” A London Plane-Tree, and Other Verse, 39. London: T. Fisher Unwin. Print.

---. 1993. “Jewish Children.” [1886] In The Complete Novels and Selected Writings of Amy Levy. Ed. Melvyn New, 528-531. Florida: University Press of Florida. Print.

---. 1993. The Romance of a Shop [1888]. In The Complete Novels and Selected Writings of Amy Levy. Ed. Melvyn New, 59-196. Florida: University Press of Florida. Print. 
Loncraine, Rebecca. 2003. “The Book of Repulsive Women: Djuna Barnes’ Unknown Poetry.” PN Review 29 (6): 40-45. Print.

Marsh, Jan. 2010. The Legend of Elizabeth Siddal. London: Quartet Books.

Nead, Lynda. 2000. Victorian Babylon: People, Streets, and Images in Nineteenth-Century London. New Haven: Yale University Press.

New, Melvyn. 1993. Introduction. In The Complete Novels and Selected Writings of Amy Levy. Ed. Melvyn New, 1-52. Florida: University Press of Florida. Print.

Parsons, Deborah. 2000. Streetwalking the Metropolis: Women, the City and Modernity. Oxford: Oxford University Press. Print.

Poe, Edgar Allen. 1846. “The Philosophy of Composition.” Graham’s Magazine, April: 163167. Print.

Port, Cynthia. 2001. “'Money, for the night is coming': Jean Rhys and the Gendered Economies of Aging.” Women: A Cultural Review 12 (2): 204-217. Print.

Rossetti, Christina. 2008. “In an Artist’s Studio.” [1856] In Selected Poems. Ed. Dinah Roe, 49. London: Penguin. Print.

Schaffer, Talia. 2000. The Forgotten Female Aesthetes: Literary Culture in Late-Victorian England. Charlottesville: University of Virginia Press. Print.

Steptoe, Lydia [Djuna Barnes]. 1923. "What Is Good Form in Dying? In Which a Dozen Dainty Deaths Are Suggested for Daring Damsels.” Vanity Fair, June: 73+. Print.

Swinburne, Algernon Charles. 2004. Major Poems and Selected Prose. Ed. Jerome McGann and Charles L. Sligh. New Haven: Yale University Press. Print.

Tyler-Bennett, Deborah. 2001. “Thick Within Our Hair: Djuna Barnes’ Gothic Lovers.” In Gothic Modernisms. Eds. Andrew Smith and Jeff Wallace, 95-110. London: Palgrave. Print.

Vadillo, Ana Parejo. 2005. Women Poets and Urban Aestheticism: Passengers of Modernity. London: Palgrave. Print.

Zonana, Joyce. 1989. “The Embodied Muse: Elizabeth Barrett Browning’s Aurora Leigh and Feminist Poetics.” Tulsa Studies in Women's Literature 8 (2): 240-262. Print. 